\title{
PERENCANAAN PEMBANGUNAN EKONOMI WILAYAH BERBASIS PERTANIAN DALAM RANGKA PENGURANGAN KEMISKINAN DI KALIMANTAN BARAT
}

\author{
Nia Permatasari ${ }^{1}$, Dominicus Savio Priyarsono², dan Amzul Rifin ${ }^{3}$ \\ 1)Program Studi Ilmu Perencanaan Pembangunan Wilayah dan Perdesaan, \\ Fakultas Ekonomi dan Manajemen, Institut Pertanian Bogor \\ 2)Staf Pengajar Departemen Ilmu Ekonomi, Fakultas Ekonomi dan Manajemen, Institut Pertanian Bogor \\ 3)Staf Pengajar Departemen Agribisnis, Fakultas Ekonomi dan Manajemen, Institut Pertanian Bogor \\ e-mail : 1)nia.azh1714@yahoo.com
}

\begin{abstract}
Agriculture-based economic development planning is one of the efforts to reduce poverty in West Kalimantan by synergizing the performance of regional finance and agriculture sectors. The present study aimed at identifying relationship between the performance of regional finance, the performance of agriculture sector and poverty level of West Kalimantan. Analytical tools used to achieve the objectives of this research were descriptive statistics and panel data methods. The results show a positive relationship between the performance of regional finance and agriculture sectors. Gradual reallocation of agricultural budget can be an option for government to determine annual budget. Increase in preparatory investment and reallocation of regional government investment is a necessary policy to give allocation priority for agriculture sectors development. The agriculture sectors, in this case the segment of agriculture sectors on GRDP of West Kalimantan, negatively affect the poverty level. The development of agriculture sectors run by the government should be followed by the increase in human resources quality.
\end{abstract}

Keywords: agriculture sector, poverty, regional economic development.

\section{PENDAHULUAN}

Kalimantan Barat merupakan salah satu provinsi di Indonesia yang mempunyai letak strategis. Wilayah daratnya berbatasan langsung dengan negara Malaysia yang sudah memiliki pintu perbatasan antar-negara yang resmi. Sedangkan wilayah lautnya dilintasi oleh pelayaran perdagangan internasional. Kondisi demikian membuat Kalimantan Barat memiliki keunggulan secara geografis, namun di sisi lain kondisi perekonomian dan kesejahteraan masyarakat masih tertinggal dengan daerah lain. Hal ini ditunjukkan dari data BPS bahwa pada tahun 2012 Provinsi Kalimantan Barat mempunyai perkembangan perekonomian lebih lambat $(5.39 \%)$ dibandingkan perekonomian nasional (6.2\%) dan memiliki jumlah penduduk miskin terbanyak di Pulau Kalimantan. Sehingga diperlukan suatu upaya untuk meningkatkan perekonomian daerah agar dapat menyelesaikan permasalahan tersebut. Kunci keberhasilan suatu pembangunan adalah peren- canaan yang tepat. Perencanaan pada hakekatnya harus didasarkan pada masalah, kebutuhan dasar dan potensi wilayah agar pembangunan yang dilakukan tepat guna dan tepat sasaran sehingga mampu meningkatkan perekonomian daerah.

Salah satu indikator untuk mengukur keberhasilan pembangunan ekonomi yaitu melalui angka Produk Domestik Regional Bruto (PDRB). Distribusi persentase PDRB atas dasar harga konstan tahun 2000 menurut lapangan usaha di Provinsi Kalimantan Barat tahun 2008-2013, menunjukkan bahwa sektor pertanian memberikan kontribusi tertinggi dibanding sektor lainnya. Sektor pertanian di Kalimantan Barat memberikan kontribusi sebesar 24.48\% jauh lebih tinggi dari kontribusi sektor pertanian nasional yang besarnya $12.26 \%$. Kontribusi yang relatif besar ini sangat berpengaruh dalam meningkatkan kesejahteraan masyarakat Kalimantan Barat khususnya petani. Seperti yang dikemukakan Priyarsono (2013), sektor pertanian masih memegang peranan penting dalam mewujud- 
kan pertumbuhan ekonomi yang tinggi dan distribusi pendapatan yang merata dibandingkan sektor lainnya.

Wilayah Kalimantan Barat sebagian besar merupakan dataran rendah dengan luas $146807 \mathrm{~km}^{2}$ atau $7.53 \%$ dari luas Indonesia, sehingga memiliki potensi yang besar di bidang pertanian. Sektor pertanian merupakan kontribusi utama dalam struktur perekonomian masyarakat Kalimantan Barat. Hampir 60\% dari 4.47 juta jiwa penduduknya bergerak di bidang pertanian (BPS, 2013). Luas lahan yang besar, sumberdaya manusia yang potensial, serta kondisi alam yang baik menjadi faktor pendukung untuk mengembangkan usaha pertanian di Kalimantan Barat. Oleh karena itu, sektor pertanian di Kalimantan Barat perlu terus dikembangkan. Hal ini relevan dengan pendapat Arifin (2005), sektor pertanian harus tetap mendapatkan perhatian pemerintah karena memiliki dasar yang kuat sebagai penopang perekonomian nasional.

Berdasarkan peranan sektor pertanian tersebut, pemerintah daerah Provinsi Kalimantan Barat telah menetapkan agenda pembangunan ekonomi yang didasarkan kepada sektor pertanian yang sejalan dengan program revitalisasi pertanian, perikanan dan kehutanan yang digagas Kementrian Pertanian. Melalui Revitalisasi Pertanian diharapkan sektor pertanian akan menjadi tulang punggung perekonomian Provinsi Kalimantan Barat, terutama dalam meningkatkan ketahanan pangan, mengurangi kemiskinan, serta menjadi motor penggerak percepatan pembangunan ekonomi daerah. Oleh sebab itu, pemerintah Provinsi Kalimantan Barat memprioritaskan pertanian sebagai salah satu sektor unggulan agar dapat mewujudkan masyarakat Kalimantan Barat yang sejahtera.

Pemerintah daerah memerlukan informasi kemiskinan menurut sektor ekonomi untuk membuat kebijakan investasi yang berbasis kemiskinan, guna mempercepat program pengentasan kemiskinan. Jika dibandingkan dengan proporsi penduduk miskin menurut sektor lapangan usaha, proporsi belanja modal pada sektor dimana penduduk miskin paling banyak berada, masih relatif kecil dimana belanja modal untuk pertanian rata-rata hanya sebesar $1.41 \%$ selama periode 2008-2013. Pertanian menjadi sektor yang diharapkan mampu mengurangi kemiskinan, tetapi alokasi anggaran untuk sektor pertanian masih sangat kecil. Tingginya tingkat kemiskinan di pedesaan disebabkan kebijakan pembangunan bias perkotaan dan sektor industri, sementara alokasi anggaran sektor pertanian menurun drastis (Sajogyo, 2002). Salah satu karakteristik penduduk miskin secara spesifik sebagian besar tinggal di pedesaan dengan mata pencaharian dominan berusaha sendiri di sektor pertanian (Pasaribu, 2006) dan pengembangan sektor pertanian menjadi sangat penting dalam upaya menurunkan tingkat kemiskinan (Yudhoyono, 2004, Datt dan Ravallion, 1996, serta Matsuyama, 1992).

Kontribusi sektor pertanian di Kalimantan Barat, ditunjang dengan besarnya penyerapan tenaga kerja dan anggaran pembangunan pertanian yang baik, seharusnya dapat mengurangi kemiskinan. Namun faktanya proporsi belanja modal untuk sektor pertanian relatif kecil sehingga tingkat kemiskinan di Kalimantan Barat juga masih tinggi. Permasalahan penelitian adalah: (1) Bagaimana kinerja keuangan daerah, kinerja sektor pertanian dan kondisi kemiskinan di Kalimantan Barat?; (2) Bagaimana keterkaitan antara kinerja keuangan daerah, kinerja sektor pertanian dan kemiskinan di Kalimantan Barat? Adapun tujuan penelitian ini adalah: (1) Mengkaji kinerja keuangan daerah, kinerja sektor pertanian dan kemiskinan di Kalimantan Barat; (2) Mengidentifikasi keterkaitan antara kinerja keuangan daerah, kinerja sektor pertanian dan tingkat kemiskinan di Kalimantan Barat.

\section{METODE}

Penelitian ini menggunakan metode analisis deskriptif kuantitatif. Tujuan dari penelitian deskriptif kuantitatif ini adalah 
untuk membuat deskripsi, gambaran atau lukisan secara sistematis, faktual dan akurat mengenai fakta-fakta, sifat-sifat serta hubungan antar fenomena yang diselidiki berdasarkan hasil analisis berupa angkaangka (Nazir, 2003). Model ekonometrika yang digunakan untuk penelitian ini adalah analisis regresi berganda dengan data panel, yaitu menggunakan informasi dari gabungan pendekatan cross section dan pendekatan time series. Analisis ini digunakan untuk mengestimasi pengaruh variabel independen terhadap variabel dependen.

Spesifikasi model untuk melihat keterkaitan antara kinerja keuangan daerah dan kinerja sektor pertanian dapat diformulasikan sebagai berikut:

$$
\begin{gathered}
P D R B P_{i t}=\alpha_{i}+\beta_{1} T K P_{i t}+\beta_{2} P A D_{i t}+\beta_{3} A P_{i t} \\
+\beta_{4} L P_{i t}+\varepsilon_{i t}
\end{gathered}
$$

Keterangan:

PDRBP = PDRB sektor pertanian (Milyar Rp)

$\mathrm{TKP}=$ Tenaga kerja pertanian (jiwa)

$\mathrm{PAD}=$ Pendapatan asli daerah kabupaten/kota (Milyar Rp)

$\mathrm{AP}=$ Anggaran sektor pertanian kabupaten/kota (Milyar Rp)

$\mathrm{LP}=$ Luas areal lahan pertanian $(\mathrm{Ha})$

$\varepsilon_{i t} \quad=$ Errorterm

$\mathrm{i} \quad=$ Kabupaten/Kota; $\mathrm{i}=1,2,3, \ldots, 14$;

$\mathrm{t}=$ banyaknya time series; $\mathrm{t}=2008$, $2009, \ldots, 2013$

Untuk menganalisis keterkaitan antara kinerja sektor pertanian dan tingkat kemiskin- an, model yang diestimasi adalah sebagai berikut:

$$
\begin{gathered}
K_{i t}=\alpha_{i}+\beta_{1} P D R B P_{i t}+\beta_{2} P O P_{i t}+\beta_{3} P G U R_{i t} \\
+\beta_{4} P D D K N_{i t}+\varepsilon_{i t}
\end{gathered}
$$

Keterangan:

$\mathrm{K}=$ Jumlah penduduk miskin (Ribu jiwa)

ASHARE $=$ Share pertanian terhadap PDRB (persen)

POP = Jumlah populasi (Ribu jiwa)

PGUR = Jumlah pengangguran (Ribu jiwa)

PDDKN = Persentase tingkat pendidikan (Persen)

$\varepsilon_{i t} \quad=$ Errorterm

$\mathrm{i}=$ Kabupaten $/$ Kota; $\mathrm{i}=1,2,3, \ldots, 14$;

$\mathrm{t}=$ banyaknya time series; $\mathrm{t}=2008$, 2009, ..., 2013

\section{HASIL DAN PEMBAHASAN}

\section{PERKEMBANGAN KINERJA KEUANGAN PEMERINTAH KABUPATEN/KOTA}

Kemampuan suatu daerah dalam membiayai pembangunannya melalui sumber yang berasal dari daerah tersebut dapat dilihat dari proporsi PAD terhadap total penerimaan daerah melalui ukuran derajat desentralisasi fiskal. Sementara itu besarnya sumber penerimaan daerah yang berasal dari potensi sumber daya yang dimiliki oleh daerah tersebut dapat dilihat dari derajat potensi daerah yang diukur dari besarnya bagi hasil pajak/bukan pajak daerah tersebut terhadap total penerimaan daerah. Sedangkan

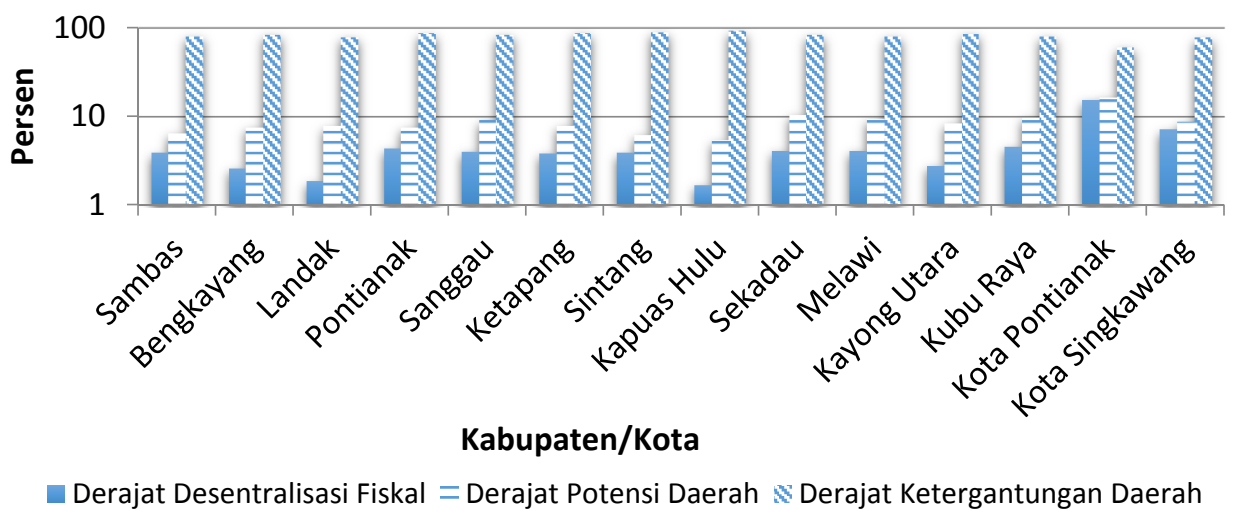
Gambar 1. Rata-Rata Nilai Derajat Desentralisasi Fiskal, Derajat Potensi Daerah dan Derajat Ketergantungan Daerah Kabupaten/Kota di Kalimantan Barat, Tahun 2008-2013
Sumber: DJPK, 2008-2013


ketergantungan penerimaan keuangan suatu daerah terhadap pemerintah pusat, dapat dilihat dari besarnya jumlah Dana Alokasi Umum dan Dana Alokasi Khusus terhadap penerimaan total daerah tersebut yang disebut derajat ketergantungan.

Selama tahun 2008-2013, rata-rata derajat desentralisasi fiskal Kabupaten/Kota yang ada di Kalimantan Barat nilainya masih rendah di bawah $10 \%$. Nilai tersebut menurut ukuran derajat desentralisasi fiskal tim Fisipol UGM termasuk dalam kategori kurang. Derajat potensi daerah Kabupaten/Kota di Kalimantan Barat secara rata-rata bernilai di bawah 15\%. Dilihat dari nilainya, derajat potensi daerah Kabupaten/Kota tersebut masih terbilang cukup rendah. Sebagian besar Kabupaten/Kota di Kalimantan Barat masih memiliki ketergantungan yang sangat tinggi terhadap dana perimbangan dari pusat, khususnya dana yang berasal dari DAU dan DAK. Berdasarkan rata-rata, nilai derajat ketergantungan fiskal Kabupaten/Kota di Kalimantan Barat adalah sebesar 80\%.

Selain proporsi penerimaan daerah terhadap total penerimaan, terdapat ukuran lain dalam mengukur tingkat kemandirian fiskal daerah, yaitu dengan membandingkannya dengan total penerimaan daerah. Menurut Halim (2007), tingkat kemandirian daerah dapat diukur melalui proporsi PAD terhadap total pengeluaran daerah dan proporsi jumlah PAD dan BHPBP terhadap total pengeluaran daerah.
Berdasarkan Gambar 2, dapat dilihat bahwa rata-rata derajat kemandirian fiskal yang diukur dari proporsi PAD terhadap total pengeluaran daerah masih terbilang rendah sekali, yaitu hanya sebesar $10 \%$. Sementara itu, rata-rata derajat kemandirian fiskal yang diukur melalui proporsi jumlah PAD dan BHPBP terhadap total pengeluaran daerah adalah 15\%. Nilai tersebut sedikit lebih tinggi apabila dibandingkan dengan derajat kemandirian fiskal yang berasal hanya dari PAD.

Dana yang diterima oleh daerah baik dari pusat dalam bentuk dana perimbangan, maupun yang diperoleh dari hasil penggalian potensi dan sumber daya yang ada di daerah kemudian dikelola dan digunakan untuk membiayai kegiatan-kegiatan pemerintah daerah dalam rangka mencapai tujuan daerah masing-masing. Pengeluaran daerah selama masa desentralisasi fiskal telah mengalami berbagai perubahan format penyajian dalam rangka menghasilkan laporan pengeluaran daerah yang semakin baik.

Belanja atau pengeluaran daerah dalam kajian ini dikelompokkan menjadi belanja langsung dan tidak langsung. Belanja langsung merupakan belanja yang dianggarkan terkait secara langsung dengan pelaksanaan program dan kegiatan, sedangkan belanja tidak langsung adalah belanja yang dianggarkan tidak terkait secara langsung dengan pelaksanaan program dan kegiatan

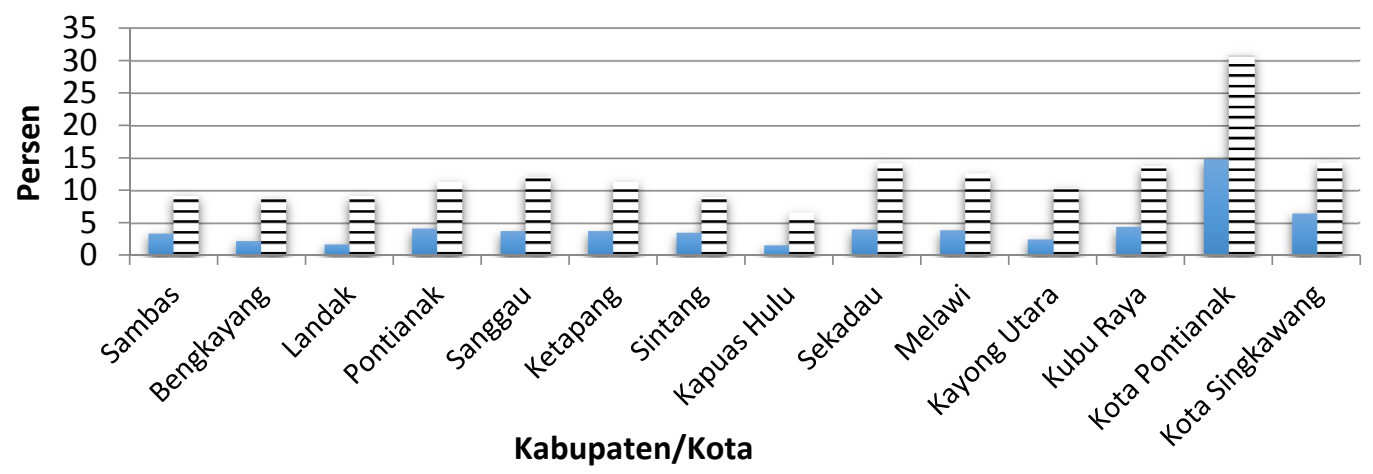

- PAD/Pengeluaran Daerah = PAD+BHPBP/Pengeluaran Daerah

\section{Gambar 2. Rata-Rata Nilai Derajat Kemandirian Daerah Kabupaten/Kota di Kalimantan Barat Tahun 2008-2013 \\ Sumber: DJPK, 2008-2013}




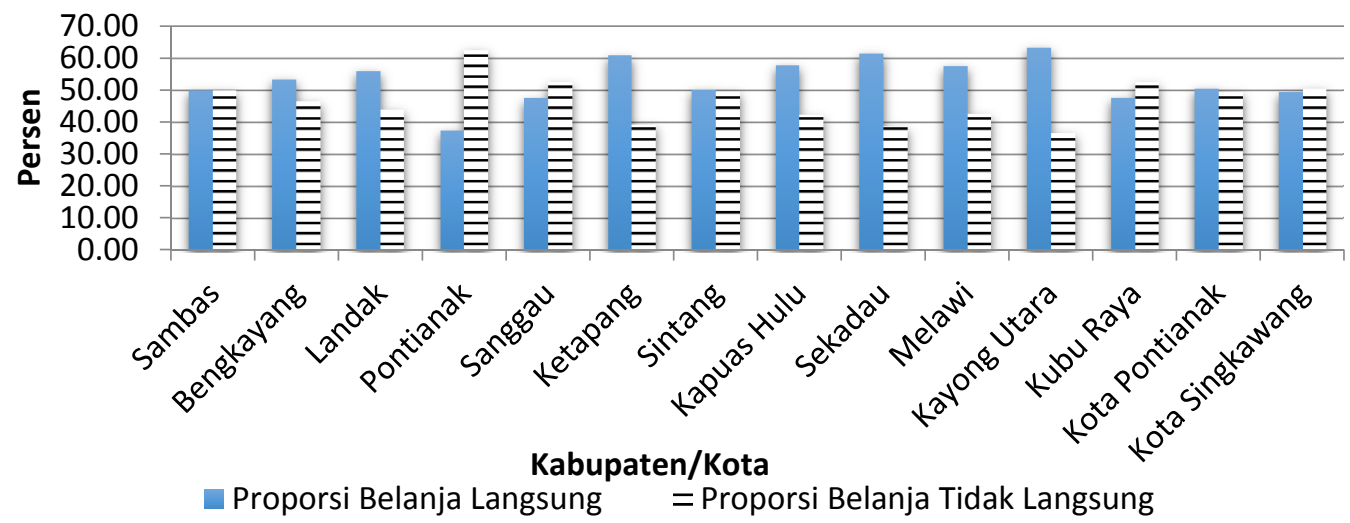

\section{Gambar 3. Rata-Rata Nilai Proporsi Belanja Langsung dan Proporsi Belanja Tidak Langsung Kabupaten/Kota di Kalimantan Barat, Tahun 2008-2013 Sumber: DJPK, 2008-2013}

Pengeluaran pemerintah selama kurun waktu 2008-2013 didominasi oleh belanja langsung. Pemerintah mengalokasikan dana bagi belanja langsung rata-rata sebesar $53.06 \%$ pertahun dari total pengeluaran pemerintah. Belanja langsung ini meliputi belanja pegawai, belanja barang dan jasa, serta belanja modal. Belanja langsung yang tinggi ini berkaitan dengan upaya pemerintah dalam meningkatkan pembangunan daerah Kabupaten/Kota di Kalimantan Barat. Ratarata proporsi belanja langsung tertinggi adalah Kabupaten Kayong Utara (63.30\%) dan terendah adalah Kabupaten Pontianak $(37.40 \%)$. Sedangkan proporsi belanja tidak langsung tertinggi adalah Kabupaten Pontianak (62.60\%) dan terendah adalah Kabupaten Kayong Utara (36.70\%).
Jika dibandingkan antara belanja pemerintah daerah untuk subsektor tanaman pangan dan peternakan, serta subsektor perkebunan, maka dapat disampaikan bahwa semua pemerintah daerah lebih fokus pada pembangunan subsektor tanaman pangan dan peternakan. Hal ini ditunjukkan oleh ratarata proporsi belanja pemerintah daerah untuk subsektor tersebut yang relatif besar.

\section{KONDISI PEREKONOMIAN KALIMANTAN BARAT}

Kondisi pertumbuhan ekonomi di Kalimantan Barat dalam kurun waktu tahun 2008 secara umum menunjukkan perkembangan yang lebih baik. Angka pertumbuhan ekonomi pada tahun 2008-2009 hanya tumbuh sebesar $5.45 \%$ dan $4.80 \%$

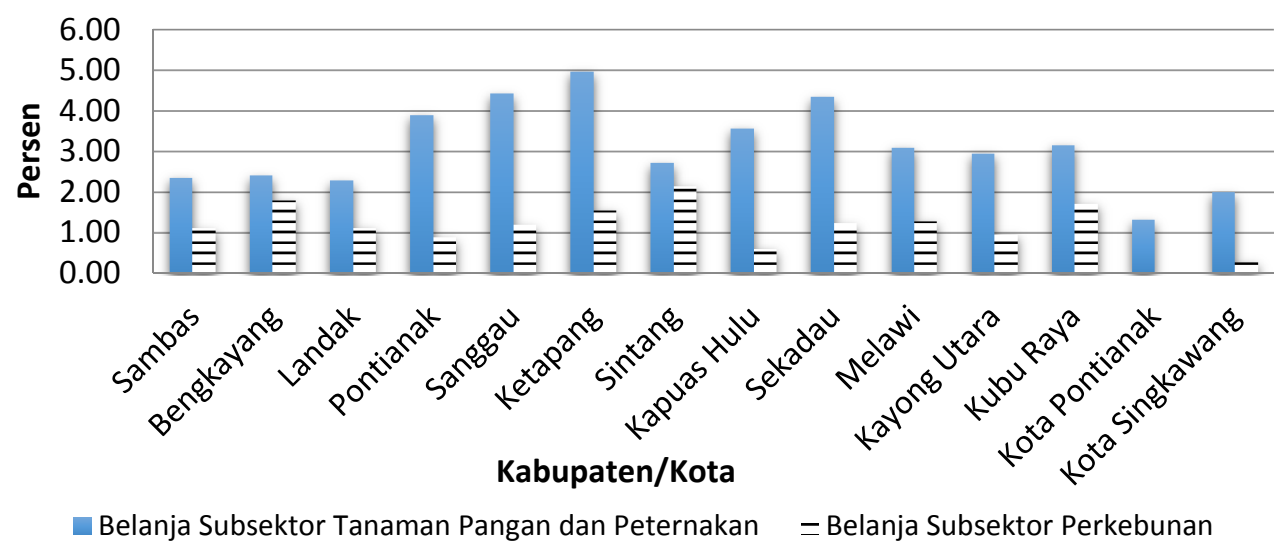

Gambar 4. Rata-Rata Nilai Proporsi Belanja Pemerintah Daerah untuk Sektor Pertanian Kabupaten/Kota di Kalimantan Barat, Tahun 2008-2013

Sumber: DJPK, 2008-2013 
Tabel 1. Pertumbuhan Sektoral Ekonomi Kalimantan Barat Tahun 2008-2013 (\%)

\begin{tabular}{|l|r|r|r|r|r|r|}
\hline \multicolumn{1}{|c|}{ Sektor } & $\mathbf{2 0 0 8}$ & $\mathbf{2 0 0 9}$ & $\mathbf{2 0 1 0}$ & $\mathbf{2 0 1 1}$ & $\mathbf{2 0 1 2}$ & $\mathbf{2 0 1 3}$ \\
\hline & 5.76 & 3.99 & 4.24 & 4.56 & 4.30 & 7.34 \\
\hline Pertanian & 10.25 & 9.03 & 8.96 & 7.07 & 5.15 & 4.70 \\
\hline Petambangan \& Penggalian & 2.11 & 0.80 & 2.23 & 2.56 & 3.10 & 4.29 \\
\hline Industri Pengolahan & 4.98 & 4.36 & 7.17 & 3.91 & 4.62 & 4.48 \\
\hline Listrik, Gas \& Air Minum & 6.44 & 7.58 & 8.23 & 9.44 & 9.78 & 5.84 \\
\hline Bangunan & 5.58 & 3.90 & 5.57 & 6.49 & 6.60 & 5.42 \\
\hline Perdagangan, Hotel \& Restoran & 12.27 & 13.29 & 10.21 & 10.69 & 6.56 & 7.06 \\
\hline Pengangkutan \& Komunikasi & 4.57 & 4.99 & 6.58 & 6.13 & 6.66 & 6.41 \\
\hline Keuangan, Persewaan \& Jasa Perusahaan & 4.51 & 5.90 & 6.08 & 6.53 & 7.71 & 6.55 \\
\hline Jasa-Jasa & $\mathbf{5 . 4 5}$ & $\mathbf{4 . 8 0}$ & $\mathbf{5 . 4 7}$ & $\mathbf{5 . 9 7}$ & $\mathbf{5 . 8 3}$ & $\mathbf{6 . 0 8}$ \\
\hline Pertumbuhan ekonomi & & & & & & \\
\hline
\end{tabular}

sebagai imbas kondisi eksternal yaitu krisis ekonomi global mulai menunjukkan perkembangan positif pada tahun 2010 yaitu sebesar 5.47\%. Pada tahun 2011 tumbuh sebesar 5.97\%. Selanjutnya, pada tahun 2012 dan 2013 tumbuh sebesar 5.83\% dan 6.08\% sehingga rata-rata pertumbuhan selama enam tahun adalah sebesar $5.60 \%$.

Secara sektoral semua sektor ekonomi mengalami pertumbuhan positif. Pertumbuhan tertinggi secara berturut-turut dialami oleh sektor bangunan $5.84 \%$, sektor jasa yaitu $6.55 \%$ dan sektor keuangan, persewaan dan jasa perusahaan yaitu $6.41 \%$. Sektor-sektor yang memiliki peranan cukup besar sebagai penggerak utama (primemover) perekonomian Kalimantan Barat adalah sektor pertanian, perdagangan dan industri pengolahan, dengan pertumbuhan masing-masing sektor adalah 7.34\%, 5.42\% dan 4.29\% (Tabel 1).

Selama kurun waktu 2008-2013, sektor pertanian merupakan sektor yang paling besar memberikan sumbangan bagi pem- bentukkan PDRB Kalimantan Barat namun peranannya terus berkurang, kondisi ini dapat menjadi indikasi terjadinya pergeseran struktur ekonomi di Kalimantan Barat. Tahun 2013 kontribusi sektor pertanian terhadap pembentukkan PDRB sebesar 24.48\% (Tabel 2). Meski demikian, secara umum sektor pertanian masih menjadi tumpuan bagi perekonomian daerah di Kalimantan Barat.

Secara nominal, PDRB sektor pertanian terbesar terdapat di Kabupaten Sambas dan terendah di Kota Pontianak. Hampir semua daerah, PDRB sektor pertanian lebih banyak disumbang oleh subsektor tanaman pangan, kecuali Kabupaten Sanggau, Ketapang, Sintang, Sekadau dan Melawi lebih banyak disumbang oleh subsektor perkebunan (Tabel 3). Komoditi unggulan pertanian tanaman pangan di Kalimantan Barat selain tanaman padi yaitu jagung, kedelai, ubi jalar dan ubi kayu. Sedangkan komoditi unggulan perkebunan yaitu kelapa sawit, karet, kelapa,

Tabel 2. Distribusi PDRB Atas Dasar Harga Konstan di Kalimantan Barat Tahun 2008-2013 (\%)

\begin{tabular}{|l|r|r|r|r|r|r|}
\hline \multicolumn{1}{|c|}{ Sektor } & $\mathbf{2 0 0 8}$ & $\mathbf{2 0 0 9}$ & $\mathbf{2 0 1 0}$ & $\mathbf{2 0 1 1}$ & $\mathbf{2 0 1 2}$ & $\mathbf{2 0 1 3}$ \\
\hline & 25.47 & 25.27 & 24.99 & 24.64 & 24.29 & 24.48 \\
\hline Pertanian & 1.65 & 1.72 & 1.78 & 1.79 & 1.78 & 1.75 \\
\hline Pertambangan \& Penggalian & 18.03 & 17.34 & 16.83 & 16.29 & 15.85 & 15.62 \\
\hline Industri Pengolahan & 0.43 & 0.43 & 0.44 & 0.42 & 0.42 & 0.42 \\
\hline Listrik, Gas \& Air Minum & 8.00 & 8.21 & 8.44 & 8.72 & 9.03 & 9.01 \\
\hline Bangunan & 21.25 & 21.07 & 21.11 & 21.22 & 21.34 & 21.22 \\
\hline Perdagangan, Hotel \& Restoran & 8.21 & 8.87 & 9.28 & 9.69 & 9.75 & 9.85 \\
\hline Pengangkutan \& Komunikasi & 5.55 & 5.56 & 5.55 & 5.56 & 5.67 & 5.69 \\
\hline Keuangan, Real Estate \& Jasa Perusahaan & 11.41 & 11.53 & 11.60 & 11.67 & 11.86 & 11.96 \\
\hline Jasa-Jasa & $\mathbf{1 0 0 . 0 0}$ & $\mathbf{1 0 0 . 0 0}$ & $\mathbf{1 0 0 . 0 2}$ & $\mathbf{1 0 0 . 0 0}$ & $\mathbf{9 9 . 9 9}$ & $\mathbf{1 0 0 . 0 0}$ \\
\hline Total & & & &
\end{tabular}

Sumber: BPS Provinsi Kalimantan Barat, 2008-2013 
Tabel 3. Rata-Rata Per Tahun PDRB Sektor Pertanian dan Kontribusi Subsektor Menurut Kabupaten/Kota di Kalimantan Barat Tahun 2008-2013

\begin{tabular}{|c|c|c|c|c|}
\hline \multirow[b]{2}{*}{ Kabupaten/Kota } & \multirow{2}{*}{$\begin{array}{l}\text { PDRB Sektor Pertanian } \\
\text { (Rp miliar) }\end{array}$} & \multicolumn{3}{|c|}{ Kontribusi Subsektor (\%) } \\
\hline & & $\begin{array}{l}\text { Tanaman } \\
\text { Pangan }\end{array}$ & Perkebunan & Peternakan \\
\hline Sambas & 1419146.84 & 29.64 & 11.05 & 1.80 \\
\hline Bengkayang & 573858.81 & 28.17 & 13.35 & 1.75 \\
\hline Landak & 837367.83 & 21.30 & 11.60 & 2.48 \\
\hline Pontianak & 324537.52 & 10.28 & 3.89 & 6.32 \\
\hline Sanggau & 975467.16 & 7.81 & 23.06 & 2.32 \\
\hline Ketapang & 909064.94 & 5.72 & 13.35 & 1.90 \\
\hline Sintang & 812868.11 & 9.73 & 19.92 & 4.49 \\
\hline Kapuas Hulu & 515738.60 & 16.30 & 6.19 & 5.02 \\
\hline Sekadau & 339990.49 & 7.71 & 34.77 & 4.21 \\
\hline Melawi & 164751.83 & 9.95 & 10.18 & 3.06 \\
\hline Kayong Utara & 192339.71 & 19.30 & 0.59 & 1.22 \\
\hline Kubu Raya & 1003836.05 & 8.31 & 4.33 & 3.89 \\
\hline Kota Pontianak & 90106.68 & 0.32 & 0 & 0.21 \\
\hline Kota Singkawang & 173627.49 & 3.86 & 2.63 & 1.79 \\
\hline
\end{tabular}

Sumber: BPS Provinsi Kalimantan Barat, 2008-2013

lada, kakao, kopi dan cengkeh. Tanaman perkebunan khususnya kelapa sawit selama ini mengalami perkembangan yang cukup pesat. Hal ini didukung oleh masuknya investasi swasta yang terus mengalami peningkatan untuk pengembangan perkebunan kelapa sawit di Kalimantan Barat. Kelapa sawit menjadi salah satu sasaran utama investasi sesuai dengan koridor ekonomi di Kalimantan dalam Masterplan Percepatan dan Perluasan Pembangunan Ekonomi Indonesia (MP3EI).

Kontribusi subsektor tanaman pangan tertinggi terdapat di Kabupaten Sambas, subsektor perkebunan di Kabupaten Sekadau dan subsektor peternakan di Kabupaten Pontianak. Berdasarkan data tersebut seharusnya tiap-tiap daerah mengenal dan memahami potensi daerahnya. Dengan mengenal dan memahami potensi daerah, pemerintah daerah dapat mengembangkan potensi tersebut guna meningkatkan PDRB demi peningkatan pendapatan penduduknya. Dalam hal ini, pemerintah daerah dapat mengalokasikan belanja daerah dalam rangka pengembangan potensi daerah.

\section{KINERJA SEKTOR PERTANIAN}

Sektor pertanian secara umum masih menjadi tulang punggung pembangunan perekonomian Kalimantan Barat, karena sektor ini memberikan kontribusi terbesar yaitu 24.48\% dari total PDRB pada tahun 2013. Sedangkan laju pertumbuhan sektor pertanian tumbuh $4.49 \%$ berasal dari subsektor tanaman pangan (3.73\%), subsektor perkebunan $(6.85 \%)$ dan subsektor peternakan tumbuh $2.84 \%$. Secara absolut nilai tambah bruto atas dasar harga berlaku pada tahun 2013 sebesar 19.61 triliun rupiah.

Seiring besarnya peranan sektor pertanian terhadap pembentukkan PDRB, sekitar $60 \%$ penduduk usia 15 tahun ke atas bekerja di sektor pertanian. Tenaga kerja pertanian tersebut tersebar ke dalam subsektor pertanian, dimana penyerapan tenaga kerja terbesar adalah subsektor perkebunan (68.61\%), tanaman pangan (26.44\%) dan diikuti peternakan (1.84\%).

Dalam mengoptimalkan pembangunan pertanian, faktor kekuatan sumber daya manusia atau ketenagakerjaan merupakan unsur yang penting dalam menggerakkan roda pembangunan di Kalimantan Barat. Jika dilihat jumlah penduduk yang bekerja di sektor pertanian berdasarkan tingkat pendidikan, maka diperoleh data bahwa jumlah penduduk berumur 15 tahun ke atas yang bekerja pada empat subsektor pertanian pada tahun 2013 paling banyak terdapat pada 


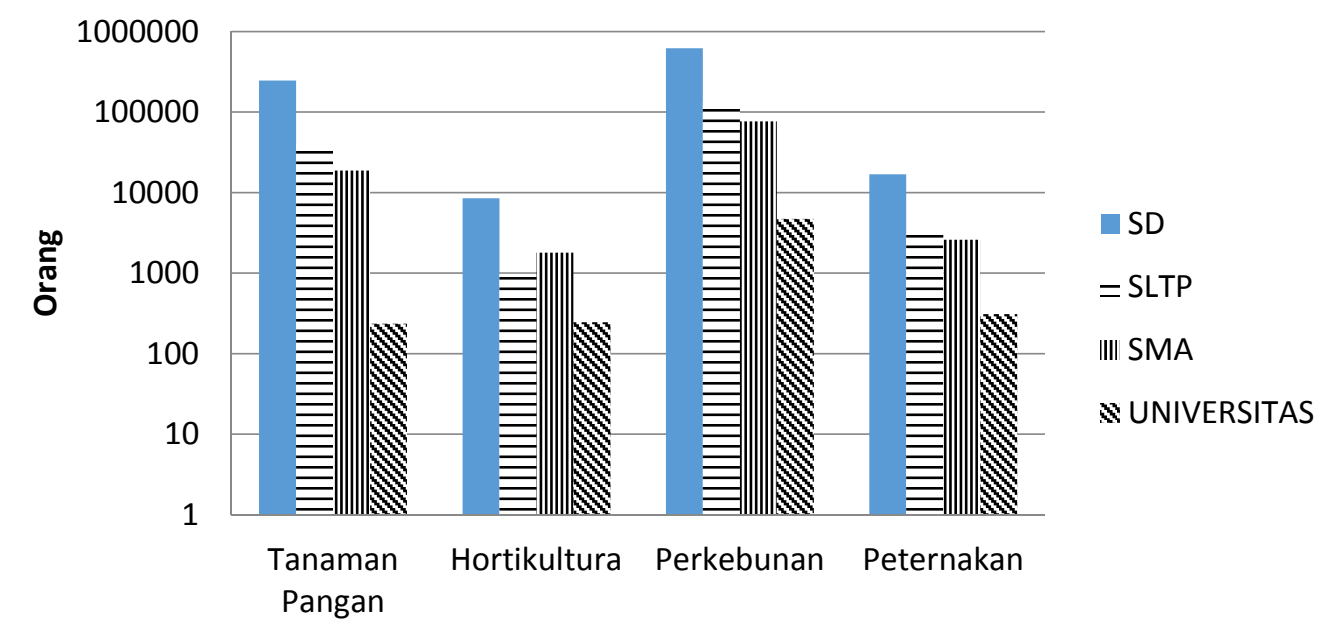

\section{Gambar 5. Jumlah Penduduk Berumur 15 Tahun ke Atas yang Bekerja di Lapangan Pekerjaan Utama Sektor Pertanian Menurut Tingkat Pendidikan Tahun 2013 Sumber: BPS, 2013}

lulusan SD (76.14\%), lulusan SLTP (14.91\%), lulusan SMA (8.47\%) dan diikuti lulusan UNIVERSITAS (0.48\%). Kondisi ini menunjukkan bahwa produktivitas tenaga kerja pertanian masih rendah, dan hal tersebut disebabkan masih rendahnya tingkat pendidikan dan kemampuan adopsi teknologi (BPS 2013). Upaya peningkatan kualitas tenaga kerja pertanian diharapkan mampu meningkatkan produktivitas, yang akhirnya mampu meningkatkan kontribusi pertanian terhadap PDRB. Oleh karena itu, diperlukan strategi yang tepat agar langkahlangkah yang diambil dapat sesuai dengan sasaran yang diharapkan. Selain itu, untuk mempertahankan dan meningkatkan kontri- busi sektor ini, dibutuhkan pelaksanaan teknologi pertanian yang utuh terutama penyediaan benih/bibit unggul bermutu.

\section{KEMISKINAN}

Perubahan tingkat kemiskinan selama periode 2008-2013 dapat dianalisis melalui perkembangan tingkat kemiskinan yang mencakup: jumlah dan persentase penduduk miskin $\left(\mathrm{P}_{0}\right)$ dan garis kemiskinan. Garis kemiskinan selama periode 2008-2013 mengalami peningkatan dari sebesar Rp 158 834 pada tahun 2008 menjadi sebesar Rp 270 306 pada tahun 2013. Peningkatan garis kemiskinan dari tahun ke tahun terjadi karena

Tabel 4. Angka Kemiskinan Kota Desa di Kalimantan Barat Tahun 2008-2013

\begin{tabular}{|c|c|c|c|c|c|c|}
\hline Indikator & 2008 & 2009 & 2010 & 2011 & 2012 & 2013 \\
\hline $\begin{array}{l}\text { Penduduk Miskin (\%) } \\
\text { (Kota+Desa) }\end{array}$ & 10,79 & 9.3 & 9.02 & 8.48 & 7,96 & 8,74 \\
\hline - Kota & 9.98 & 7.23 & 6.31 & 6.7 & 5,49 & 5,68 \\
\hline - Desa & 11.49 & 10.09 & 10.09 & 9.25 & 9,04 & 10,07 \\
\hline $\begin{array}{l}\text { Garis Kemiskinan } \\
\text { (Rp/kapita/bulan) Kota+Desa }\end{array}$ & 158834 & 174617 & 189407 & 219636 & 239162 & 270306 \\
\hline - Kota & 179261 & 194881 & 207884 & 239411 & 254972 & 279331 \\
\hline - Desa & 150968 & 166 & 182293 & 198886 & 232303 & 265898 \\
\hline $\begin{array}{l}\text { Jumlah penduduk miskin (ribu) } \\
\text { (Kota+Desa) }\end{array}$ & 508.8 & 434.77 & 428.76 & 376.13 & 355.70 & 407.340 \\
\hline - Kota & 127.5 & & 83.43 & 89.89 & 74.230 & 80.370 \\
\hline - Desa & 381.3 & 340.79 & 345.32 & 286.24 & 281.470 & 326.970 \\
\hline
\end{tabular}


Tabel 5. Angka kemiskinan berdasarkan Kabupaten/Kota di Kalimantan Barat tahun 2008-2013

\begin{tabular}{|c|c|c|c|c|c|c|}
\hline \multirow{2}{*}{ Kabupaten/Kota } & \multicolumn{6}{|c|}{ Persentase Penduduk Miskin (\%) } \\
\hline & 2008 & 2009 & 2010 & 2011 & 2012 & 2013 \\
\hline Kab. Sambas & 11.51 & 9.96 & 10.08 & 9.38 & 8.80 & 9.90 \\
\hline Kab. Bengkayang & 9.41 & 7.82 & 7.82 & 7.25 & 6.81 & 8.01 \\
\hline Kab. Landak & 18.65 & 15.48 & 14.06 & 13.13 & 12.32 & 14.18 \\
\hline Kab. Pontianak & 7.81 & 5.46 & 6.41 & 5.97 & 5.60 & 6.30 \\
\hline Kab. Sanggau & 6.25 & 4.62 & 5.02 & 4.67 & 4.38 & 4.71 \\
\hline Kab. Ketapang & 15.21 & 13.08 & 13.67 & 12.75 & 11.97 & 12.85 \\
\hline Kab. Sintang & 13.61 & 11.55 & 9.76 & 9.07 & 8.51 & 10.09 \\
\hline Kab. Kapuas Hulu & 11.44 & 9.93 & 11.39 & 10.61 & 9.96 & 11.11 \\
\hline Kab. Sekadau & 7.66 & 6.42 & 6.77 & 6.30 & 5.91 & 6.93 \\
\hline Kab. Melawi & 14.80 & 12.62 & 13.77 & 12.93 & 12.14 & 13.70 \\
\hline Kab. Kayong Utara & 14.50 & 12.43 & 11.69 & 10.91 & 10.24 & 10.87 \\
\hline Kab. Kubu Raya & - & 6.78 & 7.14 & 6.67 & 6.26 & 6.04 \\
\hline Kota Pontianak & 9.29 & 6.38 & 6.62 & 6.15 & 5.77 & 5.56 \\
\hline Kota Singkawang & 7.89 & 6.20 & 6.12 & 5.69 & 5.34 & 6.50 \\
\hline Kalimantan Barat & 11.07 & 9.30 & 9.02 & 8.48 & 7.96 & 8.74 \\
\hline
\end{tabular}

pengaruh inflasi pada komoditi makanan maupun non makanan yang menjadi dasar penentuan garis kemiskinan. Garis kemiskinan di Kalimantan Barat merupakan yang terendah diantara provinsi lainnya di Kalimantan, sedangkan jumlah dan persentase penduduk miskinnya merupakan yang terbesar diantara provinsi lain di Kalimantan. Jumlah penduduk miskin di Kalimantan Barat pada tahun 2008 sebesar 508.8 ribu jiwa atau $10.79 \%$ penduduknya merupakan golongan miskin. Selama periode 2008-2013 tingkat kemiskinan berfluktuatif hingga pada tahun 2012 jumlah penduduk miskin telah mengalami penurunan menjadi sebesar 355.70 ribu jiwa atau hanya tinggal $7.96 \%$ dari seluruh penduduk Kalimantan Barat. Namun pada tahun 2013 kembali mengalami kenaikan sebesar 407.30 ribu jiwa atau sebesar $8.74 \%$. Hal ini terjadi sebagai dampak adanya kenaikan harga bahan bakar minyak yang menyebabkan terjadinya inflasi dan penurunan daya beli.

Secara absolut jumlah penurunan penduduk miskin pada periode 2008-2013 sebesar 95.49 ribu jiwa atau secara relatif mengalami penurunan sebesar $2.13 \%$. Sebagai gambaran kondisi angka kemiskinan di Kabupaten/kota, pada tahun 2013 tercatat bahwa angka kemiskinan terendah terjadi di Kabupaten Sanggau yaitu sebesar $4.71 \%$ dan tertinggi di Kabupaten Landak sebesar $14.18 \%$.

Penurunan jumlah penduduk miskin adalah sebuah keberhasilan dalam pengentasan kemiskinan yang merupakan salah satu tujuan yang ingin dicapai dalam Millenium Development Goals (MDGs). Namun demikian, usaha untuk menurunkan tingkat kemiskinan yang lebih rendah dan mempertahankannya membutuhkan kebijakan dan usaha yang lebih efektif. Pemahaman tentang karakteristik penduduk miskin sangat diperlukan dalam merumuskan kebijakan pengentasan kemiskinan yang efektif dan berkelanjutan. Karakteristik penduduk miskin yang perlu diketahui dalam merumuskan kebijakan pengentasan kemiskinan adalah karakteristik pendidikan. Karakteristik pendidikan yang akan dianalisis adalah persentase penduduk miskin menurut tingkat pendidikan tertinggi yang ditamatkan.

Tingkat pendidikan juga berperan dalam mempengaruhi angka kemiskinan. Penduduk yang berpendidikan lebih baik biasanya akan mempunyai peluang yang lebih rendah menjadi miskin. Tabel 6 menunjukkan persentase penduduk miskin usia 15 tahun ke atas menurut Kabupaten/Kota dan pendidikan yang ditamatkan. Terlihat bahwa persentase penduduk miskin yang tidak tamat SD dan tamat SD berturut-turut sebesar $44.64 \%$ dan 
Tabel 6. Persentase Penduduk Miskin Usia 15 Tahun ke atas Menurut Kabupaten/Kota dan Pendidikan yang Ditamatkan di Kalimantan Barat Tahun 2013

\begin{tabular}{|l|r|r|r|}
\hline \multicolumn{1}{|c|}{ Kabupaten/Kota } & R SD & Tamat SD/SMP & SMA+ \\
\hline Kab. Sambas & 61.91 & 36.36 & 1.74 \\
\hline Kab. Bengkayang & 50.58 & 47.23 & 2.18 \\
\hline Kab. Landak & 45.27 & 47.53 & 7.20 \\
\hline Kab. Pontianak & 52.12 & 43.76 & 4.12 \\
\hline Kab. Sanggau & 33.51 & 66.49 & - \\
\hline Kab. Ketapang & 33.13 & 57.99 & 8.88 \\
\hline Kab. Sintang & 45.01 & 50.27 & 4.71 \\
\hline Kab. Kapuas Hulu & 36.08 & 48.32 & 15.60 \\
\hline Kab. Sekadau & 41.79 & 56.81 & 1.40 \\
\hline Kab. Melawi & 41.18 & 56.76 & 2.06 \\
\hline Kab. Kayong Utara & 59.45 & 34.14 & 6.40 \\
\hline Kab. Kubu Raya & 47.39 & 43.15 & 9.46 \\
\hline Kota Pontianak & 40.97 & 49.79 & 9.24 \\
\hline Kota Singkawang & 52.70 & 42.26 & 5.04 \\
\hline Kalimantan Barat & 44.64 & 49.20 & 6.16 \\
\hline
\end{tabular}

Sumber: BPS Provinsi Kalimantan Barat, 2013

49.20\%. Indikasi ini menunjukkan bahwa mereka yang tergolong miskin cenderung berpendidikan rendah, perubahan kebijakan wajib belajar 9 tahun juga turut berpengaruh terhadap distribusi penduduk miskin menurut tingkat pendidikan terakhir meskipun pergeseran tersebut belum mampu membebaskan mereka dari kemiskinan.

\section{KEMISKINAN SEKTOR PERTANIAN}

Kemiskinan adalah suatu fenomena atau proses multidimensi, yang artinya kemiskinan disebabkan oleh banyak faktor.
Namun, di Kalimantan Barat kemiskinan merupakan suatu fenomena yang erat kaitannya dengan kondisi sosial ekonomi di perdesaan pada umumnya dan di sektor pertanian pada khususnya. Oleh sebab itu, fenomena kemiskinan di Kalimantan Barat tidak dapat dipahami sepenuhnya tanpa memahami fenomena kemiskinan di perdesaan atau sektor pertanian.

Penduduk di sektor pertanian pada umumnya selalu lebih miskin dibandingkan penduduk yang sumber utama pendapatannya dari sektor-sektor lainnya, terutama industri manufaktur, keuangan dan

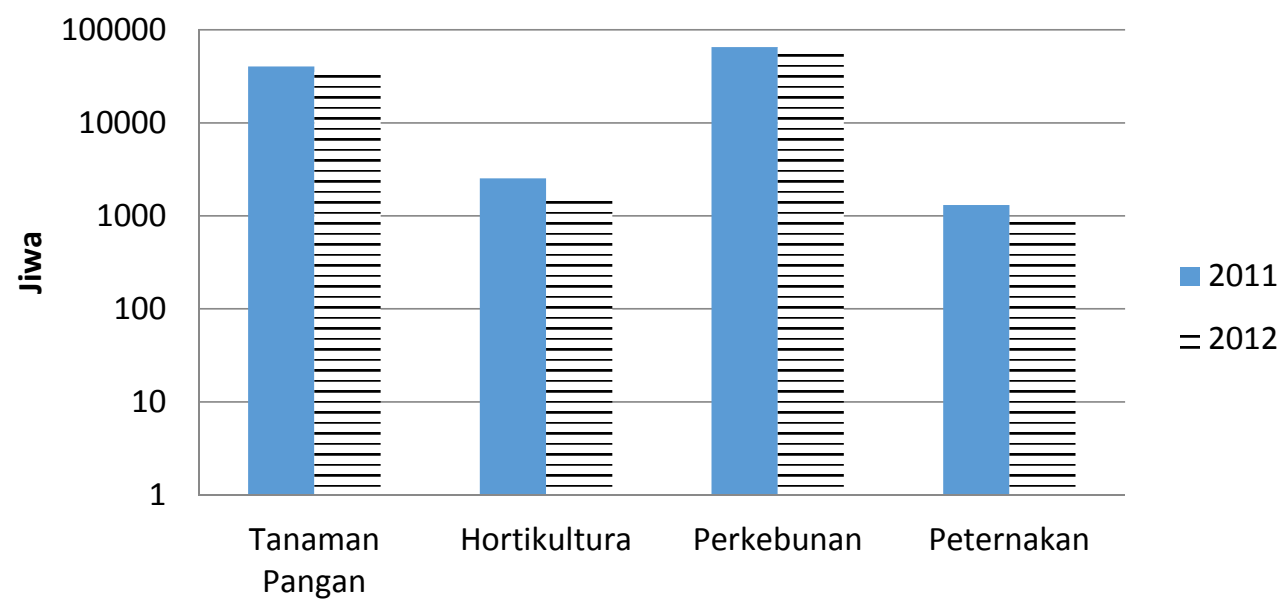

Gambar 6. Jumlah Penduduk Miskin Usia 15 Tahun ke Atas Berdasarkan Sektor Pertanian di Kalimantan Barat Tahun 2011-2012

Sumber: BPS, 2011-2012 
perdagangan; walaupun pendapatan bervariasi menurut subsektor atau kelompok usaha di masing-masing sektor tersebut.

Jika dilihat jumlah penduduk miskin berdasarkan lapangan pekerjaan maka diperoleh data bahwa jumlah penduduk miskin yang berumur 15 tahun ke atas yang bekerja pada sektor pertanian pada tahun 2012 terdapat 101716 orang yang terdiri dari 35098 orang yang bekerja pada subsektor tanaman pangan, 1481 orang yang bekerja pada subsektor hortikultura, 64268 orang pada subsektor perkebunan dan 870 orang yang bekerja pada subsektor peternakan. Penduduk miskin yang paling besar jumlahnya adalah yang bekerja pada subsektor perkebunan yakni $63.18 \%$ dari total penduduk miskin sektor pertanian dan yang bekerja pada subsektor tanaman pangan yakni $34.51 \%$ dari total penduduk miskin sektor pertanian. Hal ini dapat dilihat pada Gambar 6.

Persentase penduduk miskin 15 tahun ke atas berdasarkan lapangan pekerjaan utama menurut Kabupaten/Kota di Kalimantan Barat menunjukkan bahwa persentase penduduk miskin yang paling tinggi pada subsektor perkebunan terdapat di Kabupaten Landak yakni $16.92 \%$, sedangkan persentase yang paling rendah terdapat di Kota Pontianak yakni hanya sebesar $0.29 \%$.

Pada subsektor tanaman pangan persentase penduduk miskin yang paling tinggi terdapat di Kabupaten Sambas 22.42\%, sedangkan persentase penduduk miskin terendah terdapat di Kota Pontianak yaitu $0.76 \%$. Pada subsektor hortikultura persentase penduduk miskin yang paling tinggi terdapat di Kabupaten Pontianak yaitu 63.61\%, sedangkan persentase penduduk miskin terendah terdapat di Kabupaten Kubu Raya yakni $4.11 \%$. Pada subsektor peternakan persentase penduduk miskin yang paling tinggi terdapat di Kota Pontianak 28.05\%, sedangkan persentase penduduk miskin terendah terdapat di Kabupaten Kubu Raya yakni sebesar $6.32 \%$.

\section{KETERKAITAN ANTARA KINERJA KEUANGAN DAERAH DENGAN KINERJA SEKTOR PERTANIAN}

Pengaruh kinerja keuangan daerah terhadap kinerja sektor pertanian diestimasi melalui pengujian menggunakan analisis regresi berganda dengan data panel. Metode yang digunakan pada penelitian adalah metode fixed effect, hal ini karena data yang digunakan meliputi semua undividu dalam populasi. Pemilihan model antara metode fixed effect dan metode random effect juga dilakukan dengan pengujian Hausman test.

Hasil pengujian Hausman test menunjukkan bahwa untuk periode penelitian 2008-2013 nilai chi square hitung lebih besar daripada chi square Tabel $\left(X_{\text {hitung }}^{2}>X_{\text {tabel }}^{2}\right)$, sehingga cukup bukti untuk menolak $\mathrm{H}_{0}$. Dengan demikian estimasi menunjukkan bahwa pendekatan fixed effect lebih baik dibandingkan dengan pendekatan random effect. Berarti terdapat perbedaan antar unit yang dapat dilihat melalui perbedaan dalam constans term. Dalam fixed effect model diasumsikan bahwa tidak terdapat time

Tabel 7. Hasil Estimasi Pengaruh Kinerja Keuangan Daerah terhadap Kinerja Sektor Pertanian

\begin{tabular}{|c|c|c|c|c|c|}
\hline Variable & Coefficient & t-Statistic & P-value & Elastisitas & $\mathbf{R}$ square ( $\left.\mathbf{R}^{2}\right)$ \\
\hline Intercept & 877998.9 & 4.304256 & 0.0001 & & 0.865521 \\
\hline TKP & 4.153702 & 2.949438 & 0.0044 & 0.187093 & \\
\hline PAD & 0.155803 & 0.591998 & 0.5559 & - & \\
\hline $\mathrm{AP}$ & 6.953845 & 4.798018 & 0.0000 & 0.192637 & \\
\hline LP & 2.585951 & 0.434907 & 0.6650 & - & \\
\hline
\end{tabular}

Sumber: data diolah

Keterangan: signifikan pada $\alpha=5 \%$ 
specific effect dan hanya memfokuskan pada individual specific effects.

Hasil estimasi yang dilakukan pada periode 2008-2013 menunjukkan variabelvariabel komponen keuangan daerah dan kapasitas sektor pertanian berpengaruh terhadap kinerja sektor pertanian. Hasil pengujian dengan metode fixed effect dirangkum dalam Tabel 7 dengan nilai koefisien determinasi $\left(R^{2}\right)$ sebesar $86.55 \%$. Koefisien ini menunjukkan bahwa $86.55 \%$ variasi kinerja sektor pertanian ditentukan oleh tenaga kerja pertanian dan pengeluaran sektor pertanian, sedangkan selebihnya $(13.45 \%)$ ditentukan oleh faktor lain.

Hasil estimasi menunjukkan bahwa intersep dan tenaga kerja pertanian dan anggaran pertanian signifikan secara statistik, dengan taraf nyata 5\% ( $a=5 \%)$. Hasil ini membuktikan bahwa keempat komponen tersebut mempengaruhi secara positif terhadap kinerja sektor pertanian. Dengan kata lain, hasil perhitungan ini menunjukkan bahwa hipotesis penelitian yang menyatakan bahwa semakin baik kinerja keungan daerah maka semakin baik juga kinerja sektor pertanian terbukti.

Penyerapan tenaga kerja di sektor pertanian berpengaruh positif dengan nilai elastisitas sebesar 0.187093 artinya apabila jumlah tenaga kerja pada sektor pertanian meningkat satu persen maka PDRB sektor pertanian meningkat sebesar $0.1871 \%$. Tenaga kerja merupakan input dalam proses produksi sektor pertanian, sehingga peningkatan jumlahnya akan memberi pengaruh pada peningkatan outputnya. Dengan tambahan tenaga kerja tersebut menyebabkan pengusahaan pertanian menjadi intensif sehingga produksi dan produktivitasnya meningkat.

Nurridzki (2002), dalam penelitiannya juga menemukan bahwa peranan tenaga kerja terhadap pertumbuhan ekonomi suatu daerah sangat besar. Bahkan setelah tahun 1990-an dia menemukan bahwa yang memberi dampak pertumbuhan ekonomi di kawasan Sumatera adalah faktor tenaga kerja. Sementara untuk pulau Jawa faktor tenaga kerja telah memberikan dampak terbesar terhadap pertumbuhan ekonomi sejak dari tahun 1985.

Anggaran sektor pertanian signifikan berpengaruh positif pada PDRB sektor pertanian. Peningkatan dana pembangunan pada sektor pertanian akan meningkatkan investasi pemerintah pada pelayanan publik di sektor pertanian sehingga akan memberi eksternalitas pada peningkatan PDRB sektor pertanian. Nilai elastisitas sebesar 0.192637 menunjukkan bahwa apabila terjadi peningkatan dana pembangunan sektor pertanian sebesar satu persen maka akan terjadi peningkatan PDRB sektor pertanian sebesar $0.1926 \%$. Elastisitas peningkatan PDRB pertanian karena penambahan anggaran pertanian lebih tinggi bila dibandingkan dengan peningkatan PDRB pertanian karena penambahan tenaga kerja pertanian. Hal tersebut sejalan dengan hasil penelitian Astuti (2007) bahwa pengeluaran untuk sektor pertanian merupakan hal yang penting berkaitan dengan sektor pertanian yang menyerap tenaga kerja.

\section{KETERKAITAN ANTARA KINERJA SEKTOR PERTANIAN DENGAN TINGKAT KEMISKINAN}

Dasar pertimbangan pemilihan model panel terbaik untuk menganalisis keterkaitan antara kinerja sektor pertanian dengan tingkat kemiskinan dilakukan dengan pengujian statistik melalui Hausman test. Berdasarkan hasil Hausman test, model yang digunakan dalam analisis ini adalah model fixed effect dengan pembobotan (cross section weights) dan coefficient covariance white cross section method dengan tujuan untuk mengoreksi masalah heteroskedastisitas, multikolinearitas dan autokorelasi.

Evaluasi model berdasarkan kriteria statisika yang pertama dapat dilihat dari nilai $\mathrm{R}^{2}$. Berdasarkan hasil estimasi, nilai $R$-Square $\left(R^{2}\right)$ atau koefisien determinasi dari model tersebut sebesar 0.944363. Hal tersebut menunjukkan bahwa variasi dalam variabel bebas, yakni PDRB pertanian, populasi dan 
Tabel 8. Hasil Estimasi Pengaruh Kinerja Sektor Pertanian terhadap Tingkat Kemiskian

\begin{tabular}{|l|r|r|r|r|r|}
\hline \multicolumn{1}{|c|}{ Variable } & Coefficient & t-Statistic & P-value & Elastisitas & R square (R) \\
\hline Intercept & 29884.39 & 8.854920 & 0.0000 & & 0.944363 \\
\hline SHARE_Pertanian & -196.0673 & -5.334269 & 0.0000 & -0.19393 & \\
Populasi & 0.020562 & 2.649130 & 0.0101 & 0.221103 & \\
Pengangguran & -178.5168 & -0.484956 & 0.6293 & - & \\
\hline Pendidikan & -361.8079 & -2.777867 & 0.0071 & -0.05318 & \\
\hline
\end{tabular}

Sumber: data diolah

Keterangan: signifikan pada $\alpha=10 \%$

pendidikan mampu menjelaskan $94.43 \%$ variasi yang terdapat pada tingkat kemiskinan, sedangkan sisanya sebesar $5.57 \%$ dijelaskan oleh variabel lain di luar model. Hal ini diperkuat dengan uji $\mathrm{F}$ yang dapat dilihat dari nilai probabilitas F-statisitik (0.0000) yang signifikan pada taraf nyata sepeluh persen menunjukkan bahwa PDRB pertanian dan populasi berpengaruh terhadap tingkat kemiskinan.

Pengujian masing-masing variabel bebas yang secara statistik berpengaruh nyata terhadap tingkat kemiskinan pada periode 2008-2013 dilakukan melalui uji-t. Uji tersebut dapat dilakukan dengan melihat probabilitas dari masing-masing variabel bebasnya. Nilai probabilitas yang kurang dari taraf nyata sepuluh persen menandakan bahwa variabel tersebut signifikan mempengaruhi tingkat kemiskinan.

Evaluasi model dengan kriteria ekonomi dilakukan dengan melihat tanda dan besaran dari variabel bebas. Dari tabel 8 diperoleh hasil bahwa variabel share PDRB sektor pertanian signifikan secara statistik mempengaruhi penurunan penduduk miskin di Kalimantan Barat. Nilai elastisitas share pertanian sebesar -0.19393 berarti peningkatan sebesar satu persen share sektor pertanian terhadap PDRB Kalimantan Barat akan mengurangi jumlah penduduk miskin sebesar 0.1939 persen dengan asumsi pengaruh variabel lain konstan.

Dengan meningkatnya PDRB pertanian maka akan meningkatkan kinerja pertanian sehingga akan meningkatkan kesejahteraan masyarakat dan mengurangi kemiskinan. Hal ini dikarenakan sebagian besar jumlah penduduk miskin bekerja di sektor pertanian.
Hasil ini sesuai dengan hasil penelitian Murohman (2014) bahwa pengembangan sektor pertanian efektif mengurangi jimlah penduduk miskin di Kalimantan Barat karena dapat menyerap tenaga kerja yang banyak dan memberikan pendapatan bagi penduduk miskin. Investasi pada sektor pertanian juga membuat jarak semakin melebar. Alokasi investasi pemerintah daerah yang memperhatikan tingkat kemiskinan sektoral secara proporsional lebih efektif dalam menurunkan tingkat kemiskinan, karena berdampak pada peningkatan output dan penyerapan tenaga kerja yang lebih tinggi.

Populasi berhubungan positif dengan jumlah penduduk miskin dengan nilai elastisitas sebesar 0.221103 artinya peningkatan penduduk sebesar satu persen akan meningkatkan jumlah penduduk miskin sebesar 0.2211 persen dengan asumsi pengaruh variabel lain konstan. Demikian pula dengan penurunan satu persen populasi akan menurunkan jumlah penduduk miskin sebesar 0.2211 persen. Elastisitas penurunan jumlah penduduk miskin karena penurunan populasi lebih tinggi bila dibandingkan dengan penurunan jumlah penduduk miskin karena share sektor pertanian terhadap PDRB.

Peningkatan jumlah penduduk apabila tidak diimbangi oleh peningatan pendapatan dan penciptaan lapangan kerja justru menimbulkan beban sehingga akan menyebabkan terjadinya kemiskinan. Hasil ini menunjukkan perlunya mengontrol pertambahan penduduk, yang memang relatif besar di keluarga miskin. Sehingga diperlukan penggalakan kembali program Keluarga Berencana, dengan fokus pada keluarga miskin. 
Variabel pendidikan juga berpengaruh signifikan mengurangi penduduk miskin di Kalimantan Barat. Nilai elastisitas pendidikan sebesar -0.05318 bearti peningkatan pendidikan sebesar satu persen akan mengurangi jumlah penduduk miskin sebesar 0.0532 persen dengan asumsi pengaruh variabel lain konstan. Pendidikan dan kemiskinan mempunyai hubungan yang sangat penting, karena pendidikan sangat berperan dalam mempengaruhi angka kemiskinan. Penduduk yang mempunyai pendidikan lebih baik akan memperoleh peluang yang lebih rendah mengalami kemiskinan. Secara umum pendidikan penduduk miskin di Kalimantan Barat didominasi oleh penduduk dengan pendidikan SLTP $(49.20 \%)$ ke bawah. Hal ini menunjukkan adanya indikasi bahwa mereka yang tergolong miskin cenderung berpendidikan rendah dan semakin tinggi tingkat pendidikan terakhir semakin kecil kemungkinan jatuh ke dalam kemiskinan. Hal tersebut sejalan dengan hasil penelitian Siregar (2008) bahwa human capital merupakan determinan penting untuk menurunkan jumlah penduduk miskin.

\section{STRATEGI PEMBANGUNAN EKONOMI WILAYAH BERBASIS PERTANIAN DALAM MENGURANGI KEMISKINAN DI KALIMANTAN BARAT}

Tujuan akhir dari kebijakan pembangunan yang dilakukan oleh pemerintah adalah kesejahteraan bagi seluruh masyarakat, termasuk di dalamnya mengurangi jumlah penduduk miskin. Mekanisme trickle down effect sering digunakan oleh pemerintah untuk mencapai tujuan akhir dari pembangunan. Pertumbuhan ekonomi menjadi tujuan utama dalam kebijakan pembangunan yang dilakukan oleh pemerintah daerah, sedangkan pemerataan pendapatan dan pengurangan kemiskinan akan terjadi dengan sendirinya. Kebijakan alokasi tambahan belanja modal sebagai bentuk investasi pemerintah memberikan hasil berbeda berdasarkan tujuan dari kebijakan pembangunan. Kebijakan dapat bertujuan meningkatkan pertumbuhan output tinggi (pro growth), penyerapan tenaga kerja yang banyak (pro job) dan pengurangan kemiskinan yang tinggi (pro poor). Pemerintah daerah harus memberikan prioritas alokasi belanja modalnya pada pengeluaran untuk pengembangan sektor pertanian.

Hasil penelitian menunjukkan bahwa sektor pertanian, dalam hal ini pangsa sektor pertanian pada PDRB Kalimantan Barat, berpengaruh negatif terhadap pengurangan kemiskinan. Hal ini memberikan satu bukti bahwa sektor pertanian memiliki potensi untuk menjadi sektor yang diandalkan, khususnya terkait dengan penanggulangan kemiskinan. Kebijakan pembangunan yang dilakukan oleh pemerintah daerah yang paling baik adalah memacu pertumbuhan ekonomi yang tinggi sekaligus efektif dalam mengurangi jumlah penduduk miskin (pro poor-growth). Sektor pertanian menjadi sektor kunci dalam pengentasan kemiskinan di Kalimantan Barat walaupun dengan produktivitas tenaga kerja yang rendah. Hal ini sesuai dengan penelitian Harun (2013), Thorbecke (1996) dan Ahmad (2011) tentang perlunya pengembangan sektor-sektor pertanian dalam mengurangi tingkat kemiskinan yang tinggi. Penerapan teknologi pada sektor pertanian harus dilakukan dalam pengembangan sektor pertanian sebagai usaha peningkatan produktivitas. Oleh karena itu, pemerintah perlu mengambil kebijakan yang mengarah kepada modernisasi pertanian, di antaranya pengembangan teknologi pertanian, penyediaan bahan-bahan dan alat produksi, serta penyediaan pasar untuk hasilhasil pertanian. Selanjutnya, diharapkan sektor pertanian akan menjadi sektor yang lebih produktif dan mampu meningkatkan kesejahteraan para petani.

Pendidikan adalah hal yang mendasar untuk meningkatkan kualitas kehidupan manusia dan menjamin kemajuan sosial dan ekonomi. Pendidikan merupakan kunci untuk menciptakan, menyerap dan menyebarluaskan pengetahuan. Oleh karena itu, pendidikan dapat dilihat sebagai komponen pertumbuhan dan pembangunan yang vital. Karena itu, pemerintah perlu menyusun 
kebijakan untuk meningkatkan pemberian keterampilan yang sifatnya aplikatif, baik itu dimasukkan ke dalam kurikulum sekolah ataupun melalui pelatihan-pelatihan di luar pendidikan formal. Kebijakan yang menetapkan wajib belajar sembilan tahun perlu dipertahankan, atau bila perlu ditingkatkan menjadi dua belas tahun. Selain itu, pembangunan fasilitas pendidikan harus tersebar secara merata, sehingga dapat dinikmati oleh semua lapisan masyarakat, termasuk masyarakat miskin.

\section{SIMPULAN}

Berdasarkan pada pembahasan pada bab sebelumnya, maka dapat disimpulkan beberapa hal. Pertama, kinerja keuangan daerah Kabupaten/Kota di Kalimantan Barat selama periode 2008-2013 masih sangat rendah. Kedua, kinerja sektor pertanian dipengaruhi secara signifikan oleh anggaran pertanian dan tenaga kerja pertanian. Ketiga, share sektor pertanian terhadap PDRB Kalimantan Barat, berpengaruh negatif terhadap tingkat kemiskinan. Jumlah penduduk berpengaruh positif dan pendidikan berpengaruh negatif terhadap pengurangan jumlah penduduk miskin.

Berdasarkan hasil analisis dan simpulan di atas, maka dapat dirumuskan beberapa saran. Pertama, pemerintah daerah harus memberikan prioritas alokasi belanja modalnya pada pengeluaran untuk pengembangan sektor pertanian. Kedua, Realokasi anggaran pertanian mungkin bukan kebijakan yang mudah untuk dilakukan di tengah keterbatasan dan politik anggaran oleh pelaksanaan program. Realokasi anggaran pertanian secara bertahap dapat dijadikan pilihan pemerintah dalam penentuan anggaran setiap tahunnya. Ketiga, pemerintah daerah dapat membuat kebijakan dalam menumbuhkan investasi swasta untuk mengimbangi kebijakan alokasi anggaran pertanian seperti pemberian stimulus dalam bentuk keringanan pajak, kemudahan perijinan dan pemberian fasilitas pendukung usaha. Keempat, kebijakan pemerintah dalam mengurangi kemiskinan dilakukan dengan memperbaiki sistem pendidikan dan mengupayakan pelatihan bagi para pekerja yang memberikan kemungkinan bagi para pekerja untuk mendapatkan pendapatan yang lebih tinggi dari sebelumnya.

\section{DAFTAR PUSTAKA}

Ahmad A. 2011. Dampak Pengembangan Perkebunan Kelapa Rakyat terhadap Kemiskinan dan Perekonomian Kabupaten Indragiri Hilir. [Disertasi]. PWD-IPB. Bogor.

Arifin B. 2005. Analisis Ekonomi Pertanian Indonesia. Penerbit Kompas. Jakarta.

Astuti UP. 2007 Dampak Kebijakan Desentralisasi Fiskal terhadap Kinerja Keuangan dan Perekonomian Daerah di Provinsi Bengkulu: Suatu Pendekatan Ekonometrika. [Disertasi]. Sekolah Pascasarjana, Institut Pertanian Bogor. Bogor.

[BPS Prov. Kalbar] Badan Pusat Statistik Provinsi Kalimantan Barat. 2013. Kalimantan Barat dalam Angka. Kalimantan Barat.

Datt G, Ravallion M. 1996. How Important to India's Poor is the Sectoral Composition of Economic Growth?: The World Bank Economic Review.

Halim A. 2007. Akuntansi Keuangan Daerah, Akuntansi Sektor Publik. Salemba Empat. Jakarta.

Harun M, Zafarullah A. 2013. Goverment's Growth, Poverty and Inequality: Journal of International Development. 11(2): 177-195.

Matsuyama K. 1992. Agriculture Productivity, Comparative Advantage and Economic Growth: Journal of Economic Theory.

Murohman. 2014. Analisis Dampak Perubahan Alokasi Investasi Pemerintah Daerah Terhadap Pengentasan Kemiskinan di Kalimantan Barat. [Tesis]. Sekolah Pascasarjana, Institut Pertanian Bogor. Bogor. 
Nazir. 2003. Metode Penelitian. Salemba Empat. Jakarta.

Nurridzki, Nanda. 2002. Peranan Pengeluaran Pembangunan Sektoral Pemerintah dan Modal Swasta terhadap Pertumbuhan Ekonomi Propinsi-Propinsi di Indonesia tahun 1983-1998. [Tesis]. Universitas Indonesia. Depok.

Pasaribu B. 2006. Poverty Profile and Alleviation Programs in Indonesia. Paper presented in Asian Regional Seminar on Poverty Allevation, held by AFPPD and IFAD. Hanoi, Vietnam.

Priyarsono DS. 2013. Dari Pertanian ke Industri: Analisis Pembangunan dalam Perspektif Ekonomi Regional. Bogor [ID]: IPB Press.

Sajogyo. 2002. Pertanian dan Kemiskinan: Jurnal Ekonomi Rakyat.

Siregar H, Wahyuniarti D. 2008. Dampak Pertumbuhan Ekonomi Terhadap Penurunan Jumlah Penduduk Miskin. Departemen Pertanian. Jakarta.

Thorbecke E, Jung HS. 1996. A Multiplier Decomposition Method to Analyze Poverty Alleviation: Journal of Development Economics. 48(2): 253277.

Yudhoyono SB. 2004. Pembangunan Pertanian dan Perdesaan Sebagai Upaya Mengatasi Kemiskinan dan Pengangguran: Analisis EkonomiPolitik Kebijakan Fiskal [Disertasi]. IEPIPB. Bogor. 